\title{
Novel poly(fluorene-alt-squaraine) derivatives having large coverage with solar spectrum
}

\author{
Jiangyong Wu, Erfu Huo, Zhibing Wu, ZhiYun Lu, Minggui Xie, Qing Jiang* \\ College of Chemistry, Sichuan University, Chengdu 610064, China. Fax: +86-028- \\ 85413601; email: jqprof@163.com
}

(Received: 18 March, 2007; published: 30 july, 2007)

\begin{abstract}
Novel main-chain-conjugated poly(fluorene-alt-squaraine) using vinyl as linkage group were synthesized through direct condensation of 9,9'-dioctylfluorene derivates and squaric acid. The resulting polyfluorenes were characterized by NMR and FT-IR. They have good solubility in common organic solvents, good thermal stability and electrochemical reversibility. The structure of donor-acceptor-donor interaction in the polymer backbone resulted in much more red-shifted absorption spectra of $500-1000 \mathrm{~nm}$, and extremely low band gaps of $\sim 1.2 \mathrm{eV}$ have been obtained. Their absorption spectra have large coverage with solar spectrum, suggesting that they are potential materials that can be used in photovoltaic devices.
\end{abstract}

\section{Introduction}

Over the last years, there has been an increasing interest in polymer-based photovoltaic devices [1-5]. Conjugated polymers are now recognized as the emerging semiconductors due to their low cost, ease of processing and flexibility; not only polymeric light emitting diodes (PLEDs) [6] are approaching commercial application, but also field effect transistors (FETs)[7], photodiodes[8], and photovoltaic devices[4, 5] are being widely studied. However, compared to inorganic materials, conjugated polymers have some serious limitations for photovoltaic materials because of their relatively low mobility of charge carriers and their narrow absorption bands that have poor coverage with solar spectrum [9, 10]. For this reason, polyfluorenes, although has been well-developed as PLED materials for their high mobility and stability[11, 12], have received less attention due to their relatively short absorption wavelength, i.e. large band gaps, since high absorption coefficient and broad absorption spectra are required for efficient harvesting of the solar energy.

Squaraines, 1,3-disubstituted derivatives of squaric acid, exhibit intense and sharp absorption bands in the visible and near IR regions and high fluorescence quantum yields, which render them attractive for optical switches [13] and dye-sensitized solar cells (DSSCs) [14], and in 2003, Ajayaghosh reported a series of polymers having extremely low optical band gap by incorporation of squaraine units [15]. Herein, we describe an alternative strategy for the design of low-band-gap polymers with a donor-acceptor-structured backbone where squaraines act as acceptor and fluorene units act as donor. The conjugation length of polymers are prolonged by employing double bond linkage between donor and acceptor, thus the absorption bands are much more broadened to the region of 500-1000 nm, while those of the squarains are narrow and generally fallen into the region of $\sim 700 \mathrm{~nm}$ [16]. Furthermore, as many of the squaraines have poor solubility in both polar and non-polar organic solvents, the introduction of 9,9-dialkyl substituted fluorene derivatives has resulted 
in much more improved solution properties, and the influence of different alkyl side chains on their absorption properties has been studied in this system as well.

\section{Results and discussion}

\section{Polymer synthesis}

As shown in Scheme 1, P1 and P2 were obtained through direct condensation of monomer 5 and 6 with squaric acid. They have good solubility in common organic solvents such as THF, $\mathrm{CHCl}_{3}, \mathrm{CHCl}_{2}$ and toluene due to the introduction of the alkyl substituted fluorene segments into the polymer backbone. GPC results, as listed in Table 1, indicated that the polymers had high weight-average molecular weights $\left(M_{w}\right)$ of 142700 and 254400 with polydispersities around 7.00 and 8.80. The polymers could be easily processed into transparent and uniform thin film by casting or spincasting from toluene solution, and were found to be air stable in both solution and solid state.
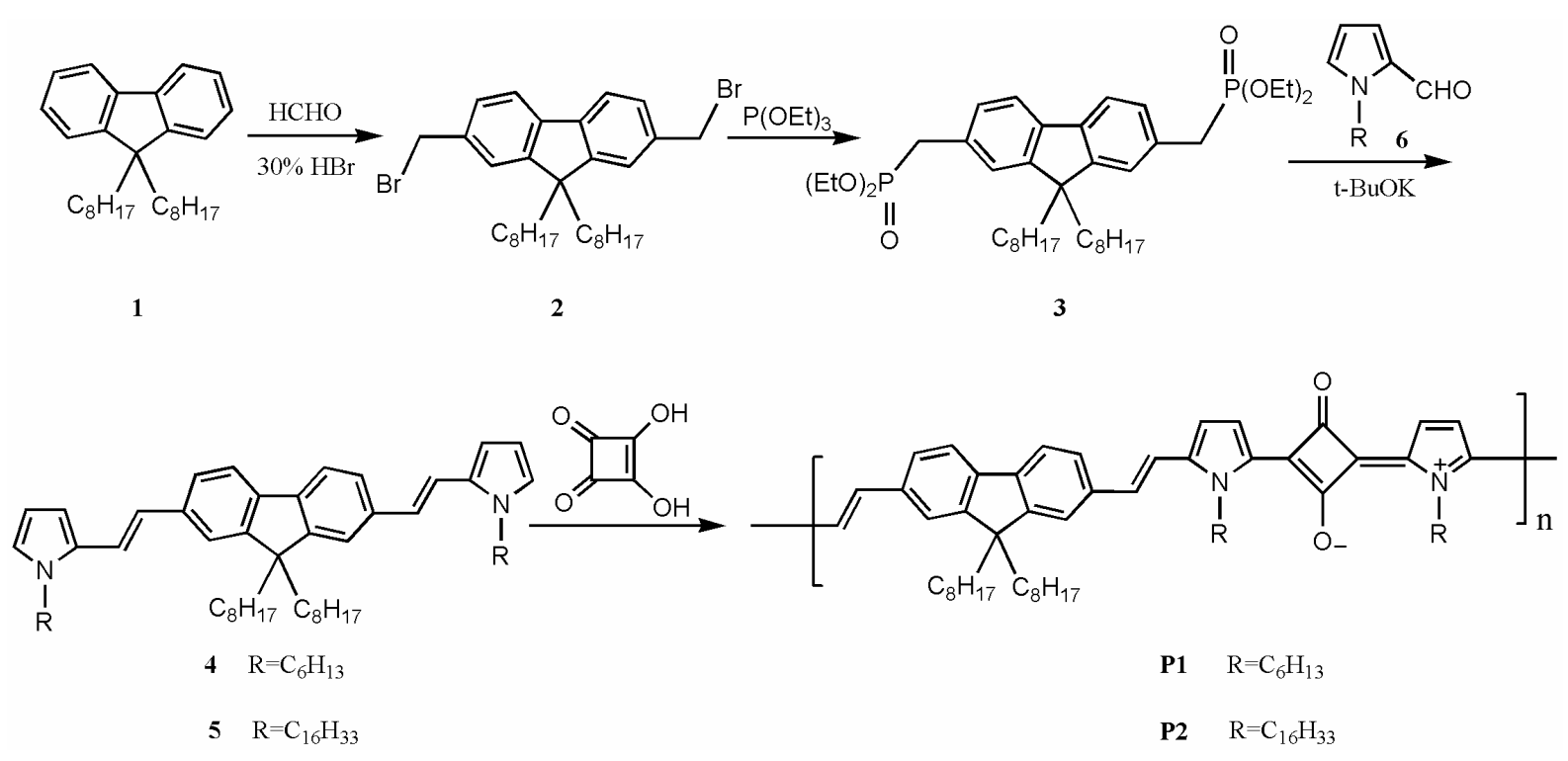

Scheme 1. The synthetic route to the monomers and the polymers.

Tab. 1. GPC and thermal analysis data of P1 and P2.

\begin{tabular}{lllllll}
\hline Polymers & Yield $\%$ & $\mathrm{M}_{\mathrm{w}}{ }^{\mathrm{a}}$ & $\mathrm{M}_{\mathrm{n}}{ }^{\mathrm{a}}$ & $\mathrm{M}_{\mathrm{w}} / \mathrm{M}_{\mathrm{n}}{ }^{\mathrm{a}}$ & $\mathrm{T}_{\mathrm{d}} /{ }^{\mathrm{b}}$ & $\mathrm{T}_{\mathrm{g}} /{ }^{\mathrm{b}}$ \\
\hline P1 & 72 & 142700 & 20400 & 7.00 & 421.23 & 158.66 \\
P2 & 68 & 254400 & 28900 & 8.80 & 407.29 & 116.42 \\
\hline \multicolumn{2}{c}{ GPC (THF), polystyrene standards. } & ${ }^{\mathrm{b}}$ TGA and DSC under nitrogen.
\end{tabular}

These polymers were characterized by their ${ }^{1} \mathrm{H}$ NMR and ${ }^{13} \mathrm{C}$ NMR and FT-IR. NMR spectra of polymer $\mathbf{P 2}$ as a representative polymer are shown in Figure 1, In the ${ }^{1} \mathrm{H}$ NMR spectrum of $\mathbf{P 2}$ in $\mathrm{CDCl}_{3}$ (Figure 1, A), the signals of the alkyl chain dominated in the region of $0.80-2.04 \mathrm{ppm}$, especially, the signals of the $\alpha-\mathrm{CH}_{2}$ of octyl group at 9-position of fluorine appeared at $2.01 \mathrm{ppm}$ and the signals of the $-\mathrm{NCH}_{2}$ and $-\mathrm{N}^{+} \mathrm{CH}_{2}$ appeared at 4.00 and $4.89 \mathrm{ppm}$. The pyrrole unit appeared at $6.18-6.70 \mathrm{ppm}$. The signals of the vinylic unit were between 6.96 and $7.14 \mathrm{ppm}$. In the ${ }^{13} \mathrm{C}$ NMR spectrum of $\mathbf{P 2}$ in $\mathrm{CDCl}_{3}$ (Figure 1, B), the signals of the squaric carbons were dominant in the region of $140.06-176.80 \mathrm{ppm}$, and the other aromatic carbons appeared in the region 
of $115.15-151.54 \mathrm{ppm}$, The signals of alkyl carbons were between 14.10 and 46.71 ppm. The NMR spectra of polymer P1 was similar to polymer P1 and is not shown. The polymers $\mathbf{P 1}$ and $\mathbf{P 2}$ were also characterized by FI-IR spectra, strong absorptions were observed at 1098, 1624, 2851 and $2923 \mathrm{~cm}^{-1}$.

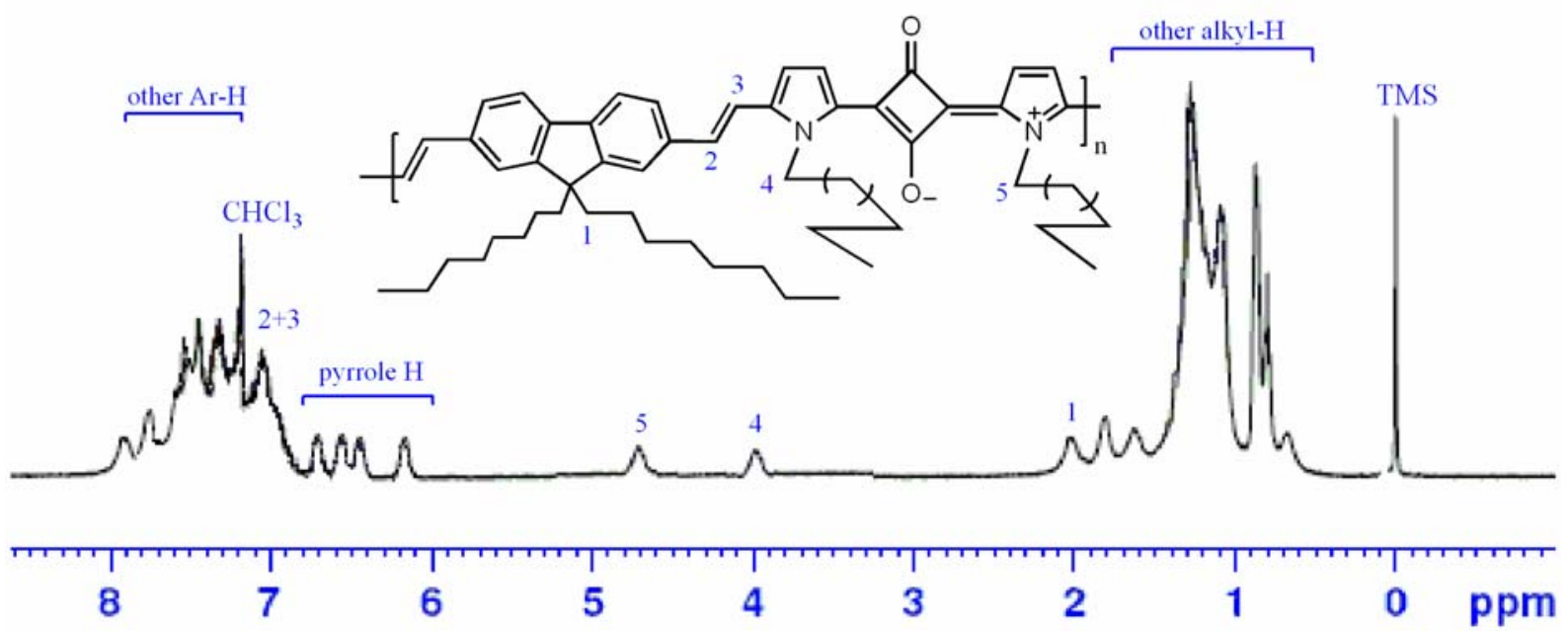

(A) ${ }^{1} \mathrm{H}$ NMR spectrum of $\mathbf{P 2}$

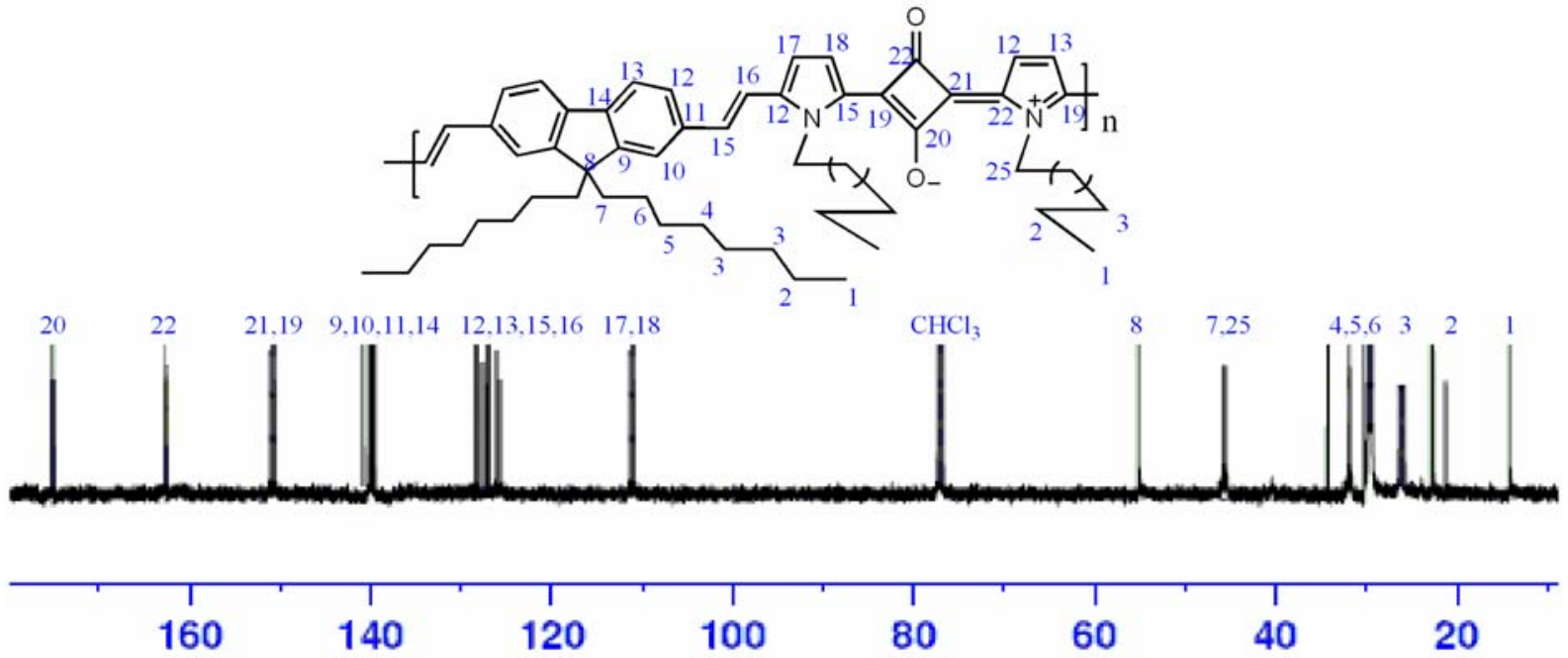

(B) ${ }^{13} \mathrm{C}$ NMR spectrum of P2

Fig. 1. NMR spectrum of polymer $\mathbf{P 2}$ in $\mathrm{CDCl}_{3}$.

The thermal properties of the polymers that determined by TGA and DSC measurements were shown in Table 1 and Figure 2. According to Figure 2, little weight loss was observed at temperatures below $400{ }^{\circ} \mathrm{C}$, and the curves fall rapidly, which suggest the polymer backbones have decomposed, at onset decomposition $\left(T_{d}\right)$ temperature of $407.29-421.23{ }^{\circ} \mathrm{C}$ under nitrogen, indicating that the target polymers exhibit good thermal stability. The glass transition temperature $\left(T_{g}\right)$ of the polymers range from $116.42{ }^{\circ} \mathrm{C}$ to $158.66{ }^{\circ} \mathrm{C}$, and these $\mathrm{T}_{\mathrm{g}}$ values are much higher than that of poly $\left(9,9\right.$-dioctylfluorene) (POF) $\left(51^{\circ} \mathrm{C}\right)$. It is obvious that the incorporation of squarain units into the main chain of polyfluorene can result in remarkable increase in $T_{g}$, which is very important for photovoltaic materials in organic solar cells. 


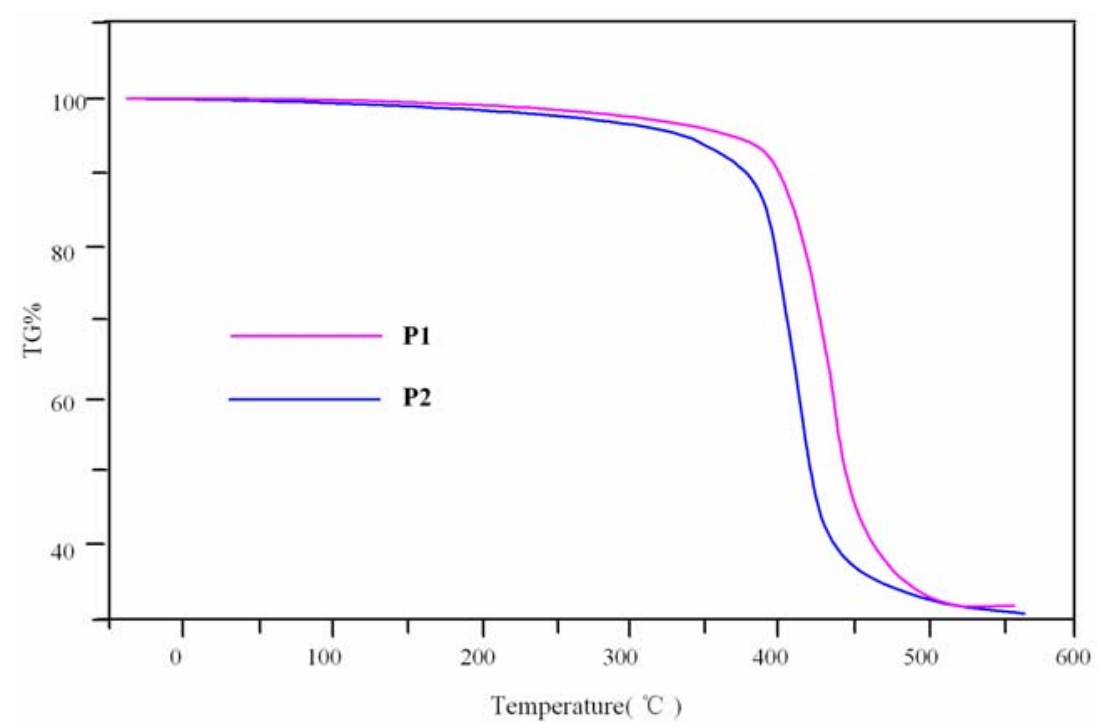

Fig. 2. Thermal gravimetric analysis (TGA) curves of the polymers under nitrogen (10 $\left.{ }^{0} \mathrm{C} / \mathrm{min}\right)$.

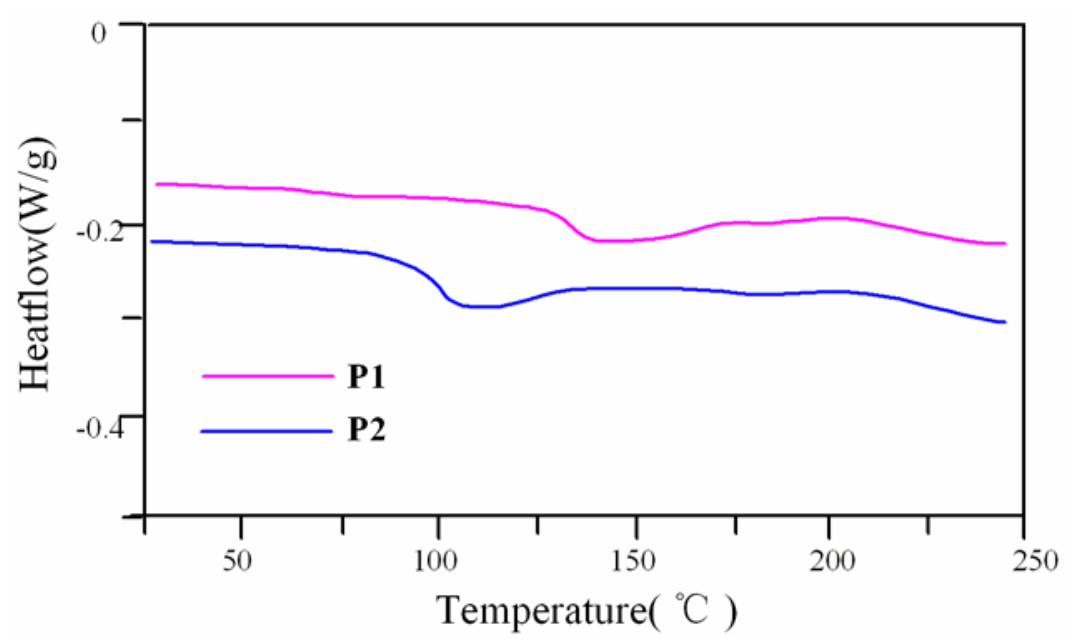

Fig. 3. Differential scanning calorimetry (DSC) curves of the polymers under nitrogen $\left(10{ }^{0} \mathrm{C} / \mathrm{min}\right)$.

\section{Optical and electrochemical analysis}

The UV-Vis-NIR absorption spectral data of polymers P1 and P2 in toluene solution are summarized in Table 2, and their spectra are shown in Figure 4(A). Their absorption band of $380 \sim 390 \mathrm{~nm}$, which is a little red-shifted compared to that of poly(9,9-dialkylfluorene) $(376 \mathrm{~nm})$, can be assigned to the $\pi-\pi^{*}$ transition of the conjugated polymer backbone. However, the target polymers P1 and P2 have broad visible and NIR absorption bands of $500 \sim 1000 \mathrm{~nm}$, as the characteristic absorption of squaraine dyes is generally a sharp and intense absorption at $\sim 700 \mathrm{~nm}$, the much broadened absorption bands are attributed to the exciton interaction and the extended conjugated length. 

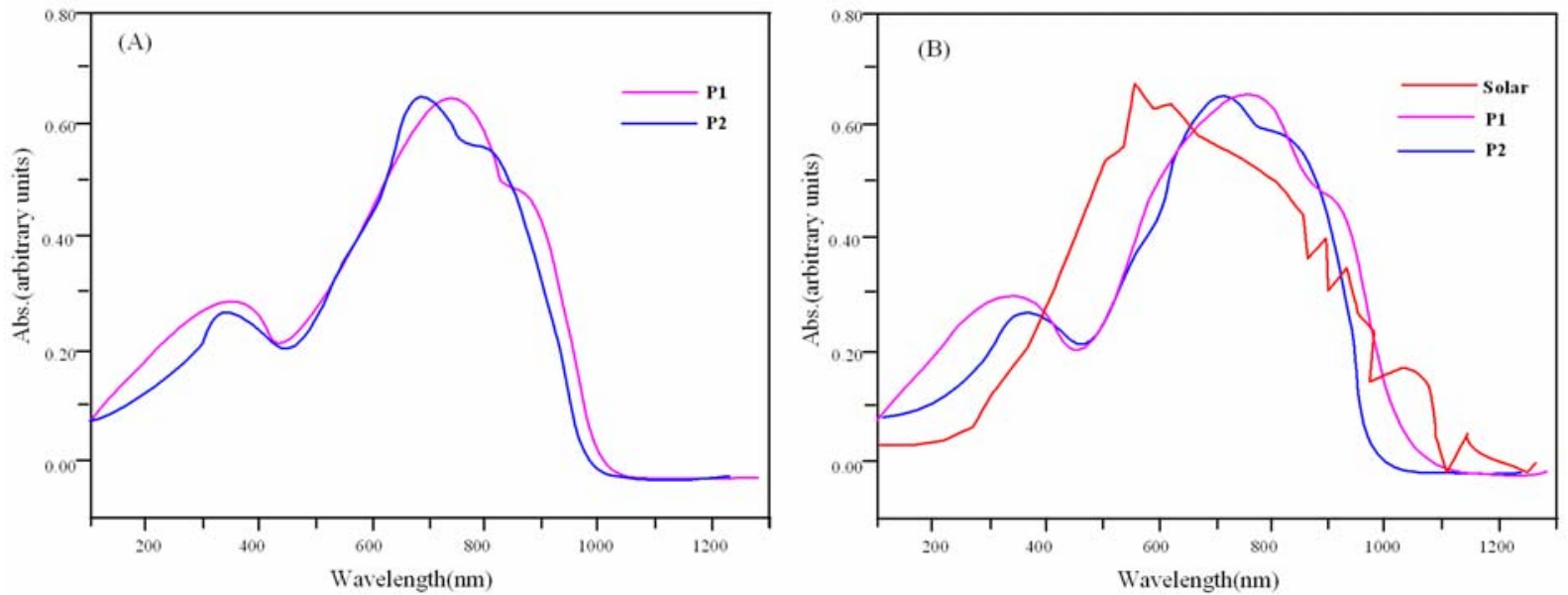

Fig. 4. (A) UV-Vis-NIR spectra of polymers in toluene; (B) The solid-state (film) absorption spectra of polymers and its overlap with solar spectrum.

Tab. 2. Optical and electrochemical properties of the polymers $P 1$ and $P 2$ in solution and film state.

\begin{tabular}{clllllllll}
\hline \multirow{3}{*}{ Polymer } & \multicolumn{3}{c}{ Solution in toluene } & \multicolumn{3}{c}{ Solid state film } & \multicolumn{3}{c}{ CV date } \\
\cline { 2 - 10 } & $\begin{array}{c}\lambda_{\max } \\
(\mathrm{nm})\end{array}$ & $\begin{array}{l}\lambda_{\text {onset }} \\
(\mathrm{nm})\end{array}$ & $\begin{array}{c}\mathrm{E}_{\mathrm{g}}{ }^{\mathrm{a}} \\
(\mathrm{eV})\end{array}$ & $\begin{array}{l}\lambda_{\max } \\
(\mathrm{nm})\end{array}$ & $\begin{array}{l}\lambda_{\text {onset }} \\
(\mathrm{nm})\end{array}$ & $\begin{array}{l}\mathrm{E}_{\mathrm{g}}{ }^{\mathrm{a}} \\
(\mathrm{eV})\end{array}$ & $\begin{array}{l}\mathrm{E}_{\text {ons }} \\
(\mathrm{eV})\end{array}$ & $\begin{array}{l}\mathrm{E}_{\text {ons }}{ }^{\text {ox }} \\
(\mathrm{eV})\end{array}$ & $\begin{array}{l}\mathrm{E}_{\mathrm{g}}{ }^{\mathrm{b}} \\
(\mathrm{eV})\end{array}$ \\
\hline P1 & 784 & 1035 & 1.20 & 796 & 1104 & 1.12 & -0.62 & 0.52 & 1.14 \\
P2 & 688 & 993 & 1.25 & 702 & 1015 & 1.22 & -0.68 & 0.55 & 1.23
\end{tabular}

${ }^{a}$ Calculated from the onset of absorption. ${ }^{\mathrm{b}}$ Estimated from the onset potentials of the oxidation and reduction processes.

The P1 with $\boldsymbol{n}$-hexyl side-chain shows broader absorption in $500-1100 \mathrm{~nm}$, whereas P2 with $n$-hexadecyl group showed relatively narrow spectra with $60 \mathrm{~nm}$ blue shifted absorption with considerable differences in the ratio of intensities of the shoulder bands. This could be assigned to an enhanced exciton coupling due to the relatively rigid and planar conformation in P1. The solid-state (film) absorption maxima, onset of absorption, and the corresponding band gaps of polymers P1 and P2 are summarized in Table 2. In general, the electronic properties such as absorption and emission of polymers are considerably different in the solid-state when compared to their solution behavior. This is mainly due to the formation of well-ordered selfassemblies of the macromolecular backbone in the case of poly(p-phenyleneethynylene)s [20] and regioregular poly(3-alkylthiophenes) [21]. The solid-state band gaps of P1 and P2 were calculated from the onset of the solid-state absorption spectra, which are 0.1-0.2 eV less, when compared to the band gap calculated from the onset of the solution absorption spectra (Table 2). Comparison of the UV-Vis-NIR absorption spectra of P1 and P2 (Figure 4) revealed that the absorption maxima and the vibronic features are significantly influenced by the length of the hydrocarbon side chains.

The cyclic voltammograms (CV) was employed to investigate the electrochemical behavior of the polymers as well as estimate the HOMO and LUMO energy levels of the materials. P1 and P2 films deposited on a platinum plate electrode were scanned as both positive and negative separately in $0.10 \mathrm{M}$ tetrabutylammonium perchlorate 
$\left(\mathrm{Bu}_{4} \mathrm{NClO}_{4}\right)$ in anhydrous acetonitrile by using platinum wires as a counter electrode and $\mathrm{Ag} / \mathrm{AgNO}_{3}(0.10 \mathrm{M})$ as reference electrode. As shown in Figure 5, the curves showed broad redox bands which may due to their polydisperse nature and intrinsic aggregation behavior.

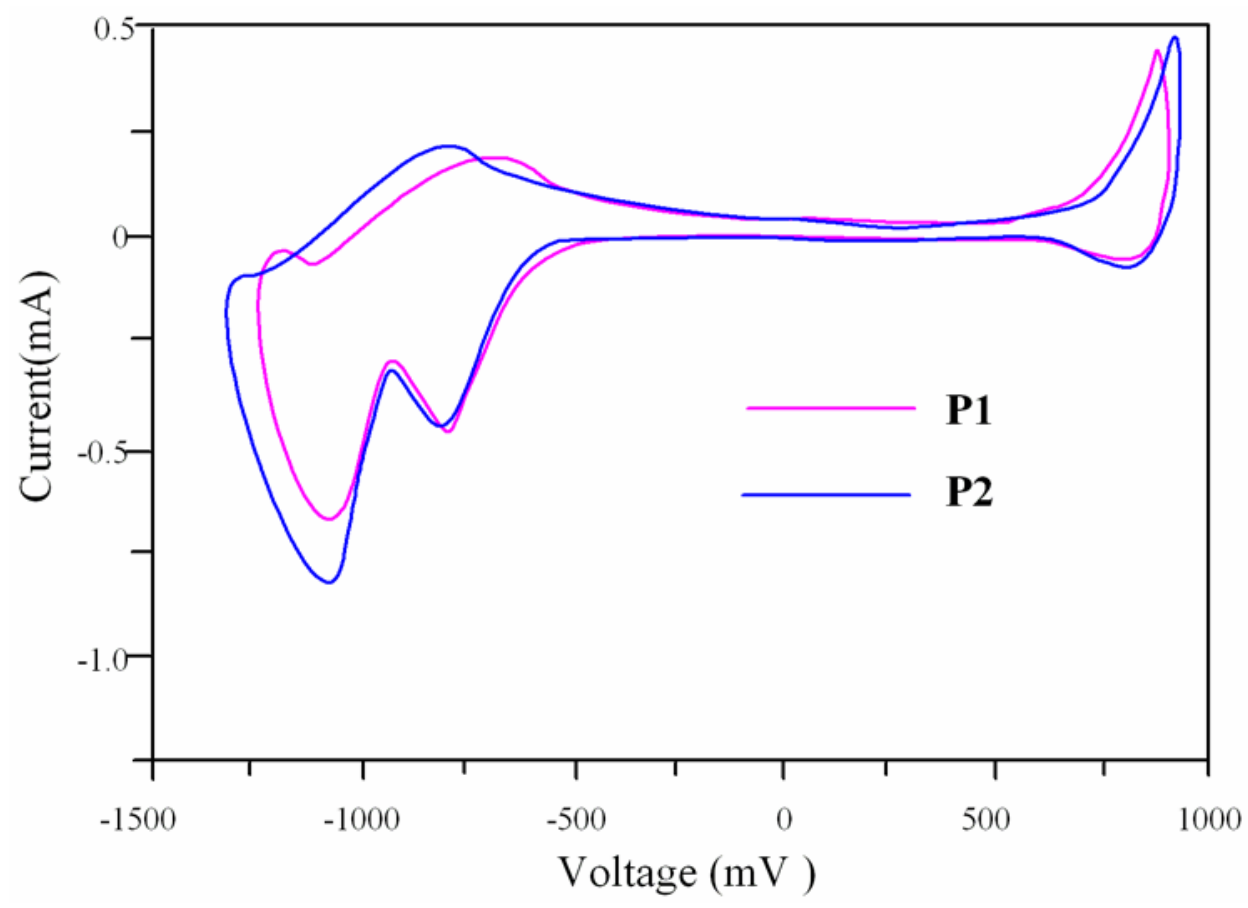

Fig. 5. Cyclic voltammograms of polymers $\mathbf{P} 1$ and $\mathbf{P} 2$ recorded at a scan rate of 50 $\mathrm{mV} / \mathrm{s}$ at room temperature.

From the onset potentials of the oxidation and reduction processes, the band gaps of polymers were estimated to be 1.14 and $1.23 \mathrm{eV}$ for polymer $\mathbf{P 1}$ and $\mathbf{P} 2$ respectively. The values are quite close to those obtained by the optical method. According to the equations [22] $\mathrm{E}_{\text {HOMO }}=\mathrm{IP}=-\left(\left[\mathrm{E}_{\text {onset }}\right]^{\mathrm{ox}}+4.4\right) \mathrm{eV}$ and $\mathrm{E}_{\mathrm{LUMO}}=\mathrm{EA}=-\left(\left[\mathrm{E}_{\text {onset }}\right]^{\text {red }}+4.4\right) \mathrm{eV}$, where $\left[E_{\text {onset }}\right]^{0 \mathrm{x}}$ and $\left[E_{\text {onset }}\right]^{\text {red }}$ are the onset potentials for oxidation and reduction of the polymer vs. the reference electrode, the LUMO and HOMO of the polymers were estimated to be $-3.78,-3.72 \mathrm{eV}$ and $-5.54,-5.63 \mathrm{eV}$ for $\mathbf{P 1}$ and $\mathbf{P 2}$.

\section{Conclusions}

By modulating the electronic absorption properties of polymers toward low optical band gap regions and strengthening the donor-acceptor interactions, a series of extremely low Eg polyfluorenes with intense NIR absorption have been synthesized. The incorporation of a 9,9'-dioctylfluorene as bridging unit with squaraine moieties can not only change the stabilities and solubility of the resulting polymers, but also adjust their optical and electronic properties. The broad and strong NIR absorption spectra of the new polymers suggest that there exists high conjugation degree and coplanarization in the polymer backbone. The absorption spectra of these novel polymers have large coverage with the solar spectrum, indicating that they are potential candidates as optical active and transition materials in solar cells. Further studies on the application as photovoltaic materials are now in progress. 


\section{Experimental part}

\section{Materials}

All the chemicals were purchased from Aldrich or Fluka Organics and were used as received unless specified. All the solvents such as THF and benzene were dried with appropriate drying agents, and distilled under reduced pressure.

\section{Measurements}

${ }^{1} \mathrm{H}$ NMR and ${ }^{13} \mathrm{C}$ NMR spectra of the samples were recorded with $400 \mathrm{MHz}$ Bruker Advance 400 instrument in $\mathrm{CDCl}_{3}$ with TMS as an internal standard. The weightaverage molecular weights $\left(M_{w}\right)$ and polydispersity indices $\left(M_{w} / M_{n}\right)$ for the polymers were determined via PL-GPC model 210 chromatograph at $25{ }^{\circ} \mathrm{C}$, using THF as the eluent and standard polystyrene as reference. TGA analysis was performed on Perkin-Elmer series 7 thermal analysis system under nitrogen at a heating rate of 10 ${ }^{0} \mathrm{Cmin}^{-1}$. DSC measurements were performed on a Perkin-Elmer DSC 7 under nitrogen at a heating rate of $10{ }^{0} \mathrm{Cmin}^{-1}$. The FT-IR spectra were obtained on a Perkin-Elmer 2000 infrared spectrometer as $\mathrm{KBr}$ pellets. The UV-Vis-NIR spectra were recorded on a Shimadzu UV-3101 PC NIR scanning spectrophotometer. The cyclic voltammograms $(\mathrm{CV})$ were recorded on a computer-controlled EG\&G potential/galvanostat model 283.

\section{Synthesis of the monomers}

9,9'-Di-n-octylflluorene(1) was synthesized following the previous reported procedure [17], and $N$-alkylpyrrole-2-carboxaldehyde(6) was prepared according to literature methods[18].

\section{-Synthesis of 2,7-bis(bromomethyl)-9,9'-di-n-octylflluorene, 2}

A mixture of $9,9^{\prime}$-di- $n$-octylflluorene $(\mathbf{1}, 3.80 \mathrm{~g}, 10 \mathrm{mmol})$, paraformaldehyde $(3.00 \mathrm{~g}, 100 \mathrm{mmol})$, and $30 \%$ of hydrobromifc acid in acetic acid $(16 \mathrm{~mL})$ was stirred at $65{ }^{\circ} \mathrm{C}$ for $24 \mathrm{~h}$. After the reaction mixture was cooled to room temperature, it was slowly poured into saturated sodium bicarbonate solution $(100 \mathrm{~mL})$. The mixture was extracted three times with dichloromethane $(100 \mathrm{~mL})$ and washed sequentially with water and saturated sodium bicarbonate solution and brine. The combined organic extracts were dried over anhydrous magnesium sulfate and filtered. After removal of the solvent, a viscous liquid 2 was obtained by column chromatography with a yield of $81 \% .{ }^{1} \mathrm{H}$ NMR $\left(\mathrm{CDCl}_{3}, \delta, \mathrm{ppm}\right): 7.63(\mathrm{~d}, \mathrm{~J}=8.4 \mathrm{~Hz}, 2 \mathrm{H}, \mathrm{Ar}-\mathrm{H}), 7.34(\mathrm{~d}, \mathrm{~J}=6.2 \mathrm{~Hz}, 4 \mathrm{H}$, Ar-H), $4.59\left(\mathrm{~s}, 4 \mathrm{H},-\mathrm{CH}_{2} \mathrm{Br}\right), 1.92\left(\mathrm{~m}, 4 \mathrm{H}, \alpha-\mathrm{CH}_{2}\right.$ of octyl group at 9-position of fluorine), 1.06-0.75 $\left(30 \mathrm{H},-\mathrm{CH}_{2}\right.$ and $\left.-\mathrm{CH}_{3}\right)$. Anal Calcd for $\mathrm{C}_{31} \mathrm{H}_{44} \mathrm{Br}_{2}: \mathrm{C}, 64.59 ; \mathrm{H}$, 7.69. Found: C, 64.61; H, 7.64.

\section{-Synthesis of (9,9'-di-n-octyl)-2,7-bis(fluorenylmethylene)-phosphonate, 3}

The synthesis of compound 3 was carried out by heating a mixture of triethyl phosphite $(6.64 \mathrm{~g}, 40 \mathrm{mmol})$ and $2(7.18,12.5 \mathrm{mmol})$ at $160{ }^{\circ} \mathrm{C}$ under nitrogen for $16 \mathrm{~h}$. After cooling, the unreacted triethylphosphite was removed under vacuum and the residue was passed through a short column of silica gel using a mixture of hexane and acetone (3:1) to afford $7.32 \mathrm{~g}$ (yield $85 \%$ ) of compound 3 as a viscous oil. ${ }^{1} \mathrm{H}$ NMR ( $\left.\mathrm{CDCl}_{3}, \delta, \mathrm{ppm}\right):$ 7.64-7.57 (m, 2H, Ar-H), 7.29-7.22 (m, 4H, Ar-H), 4.10-4.00 $\left(\mathrm{m}, 8 \mathrm{H},-\mathrm{OCH}_{2}\right), 3.98-3.20\left(\mathrm{~m}, 4 \mathrm{H},-\mathrm{PCH}_{2}\right), 1.94\left(\mathrm{~m}, 4 \mathrm{H}, \alpha-\mathrm{CH}_{2}\right.$ of octyl group at 9- 
position of fluorine),1.36-0.79 (m, $42 \mathrm{H},-\mathrm{CH}_{2}$ and $\left.-\mathrm{CH}_{3}\right)$. Anal Calcd for $\mathrm{C}_{39} \mathrm{H}_{64} \mathrm{O}_{6} \mathrm{P}_{2}$ : C,67.80; $\mathrm{H}, 9.34$. Found: $\mathrm{C}, 67.85 ; \mathrm{H}, 9.30$.

-Synthesis of (E,E)-2,7-bis[2-(1-hexylpyrrol-2-yl)vinyl]-9,9'-di-n-octylfluorene, 4

A solution of t-BuOK (1.68 g, $15 \mathrm{mmol})$ in anhydrous THF $(10 \mathrm{~mL})$ was added drop wise at ambient temperature under nitrogen to a mixture of $3(3.45 \mathrm{~g}, 5 \mathrm{mmol})$ and the corresponding $N$-hexylpyrrole-2-carboxaldehyde $(1.79 \mathrm{~g}, 10 \mathrm{mmol})$ in $20 \mathrm{ml}$ THF. After the sample was refluxed for $12 \mathrm{~h}$, the reaction mixture was cooled, and THF was removed under reduced pressure. The residue was neutralized with $5 \%$ hydrochloric acid and extracted with chloroform. The extraction was washed with water, saturated $\mathrm{NaHCO}_{3}$, and brine, then dried over anhydrous magnesium sulfate. Evaporation of solvent afforded the crude product; it was purified by column chromatography with a mixture of hexane and ethyl acetate (3:1) as eluent, yield: 65\%; M.p. 43-44 ${ }^{0} \mathrm{C}$; IR (KBr pellet, $\left.\mathrm{cm}^{-1}\right): 3059,3029,2921,2851,1463,1310,1227$, 1205, 1065, 947, 810; ${ }^{1} \mathrm{H}$ NMR $\left(\mathrm{CDCl}_{3}, \delta, \mathrm{ppm}\right): 7.62$ (d, J=16.2Hz, 2H, Ar-H), 7.47 (m, 4H, Ar-H), 7.38(s, 4H, vinylic), 6.98 (s, 2H, pyrrole- $\mathrm{H}), 6.64$ (s, 2H, pyrrole-H), 6.14(m, 2H, pyrrole-H), $4.01(\mathrm{t}, \mathrm{J}=2.82 \mathrm{~Hz}, 4 \mathrm{H}), 3.87(\mathrm{t}, \mathrm{J}=6.26 \mathrm{~Hz}, 4 \mathrm{H}), 1.97(\mathrm{~m}, 4 \mathrm{H}$, a- $\mathrm{CH}_{2}$ of octyl group at 9-position of fluorine), 1.86-1.25 (m, $\left.36 \mathrm{H}, \mathrm{CH}_{2}\right), 0.88-0.85(\mathrm{~m}$, $12 \mathrm{H}$ ).Anal Calcd for $\mathrm{C}_{53} \mathrm{H}_{76} \mathrm{~N}_{2}$ : C,85.89; $\mathrm{H}, 10.34 ; \mathrm{N}, 3.78$. Found: $\mathrm{C}, 85.98 ; \mathrm{H}, 10.28$; $\mathrm{N}, 3.74$.

-Synthesis of (E,E)-2,7-bis[2-(1-hexadecylpyrrol-2-yl)vinyl]-9,9'-di-n-octylfluorene, 5

The yellow solid was synthesized with the similar synthetic procedure for $\mathbf{4}$ from the reaction of 3 with $N$-hexadecylpyrrole-2-carboxaldehyde, yield, 73\%; M.p.26-28 ${ }^{\circ} \mathrm{C}$; IR $\left(\mathrm{KBr}\right.$ pellet, $\left.\mathrm{cm}^{-1}\right): 3046,3027,2923,2856,1468,1388,1299,1230,1037,947$, 809; ${ }^{1} \mathrm{H}$ NMR $\left(\mathrm{CDCl}_{3}, \delta, \mathrm{ppm}\right): 7.60(\mathrm{~d}, \mathrm{~J}=8.0 \mathrm{~Hz}, 2 \mathrm{H}, \mathrm{Ar}-\mathrm{H}), 7.44(\mathrm{~m}, 4 \mathrm{H}, \mathrm{Ar}-\mathrm{H}), 7.34$ (s, 4H, vinylic), 6.98 (s, 2H, pyrrole-H), $6.65(\mathrm{~s}, 2 \mathrm{H}$, pyrrole- $\mathrm{H}), 6.17(\mathrm{~m}, 2 \mathrm{H}$, pyrrole$\mathrm{H}), 4.01(\mathrm{t}, \mathrm{J}=8.0 \mathrm{~Hz}, 4 \mathrm{H}), 3.86(\mathrm{t}, \mathrm{J}=7.2 \mathrm{~Hz}, 4 \mathrm{H}), 1.96\left(\mathrm{~m}, 4 \mathrm{H}, \alpha-\mathrm{CH}_{2}\right.$ of octyl group at 9-position of fluorine), 1.86-1.25 (m, $\left.76 \mathrm{H}, \mathrm{CH}_{2}\right), 0.89-0.84(\mathrm{~m}, 12 \mathrm{H})$.Anal. Calcd for $\mathrm{C}_{73} \mathrm{H}_{116} \mathrm{~N}_{2}$ : C,85.81; $\mathrm{H}, 11.44 ; \mathrm{N}, 2.74$. Found: $\mathrm{C}, 85.92 ; \mathrm{H}, 11.36 ; \mathrm{N}, 2.71$.

\section{Synthesis of the target polymers}

\section{-The general polymeric procedure of $\mathrm{P} 1$ and $\mathrm{P} 2$}

The polymers were synthesized by an adapted literature procedure [19]. Squaric acid $(1 \mathrm{mmol})$, monomer 4 or 5 (1 mmol) and a mixture of $n$-butanol $(20 \mathrm{~mL})$ and toluene $(40 \mathrm{~mL})$ were added to a flask equipped with an azeotropic reflux condenser and refluxed under nitrogen atmosphere for $24 \mathrm{~h}$. The reaction mixture was cooled and concentrated under reduced pressure, then poured into petroleum ether to afford crude product. The precipitate obtained was collected by filtration, washed thoroughly with diethyl ether and methanol, then sohxlet extracted with methanol and acetone for $24 \mathrm{~h}$ respectively, which afforded the polymers $\mathbf{P} \mathbf{1}$ and $\mathbf{P} \mathbf{2}$.

P1: dark-blue powder, yield 72\%, IR ( $\mathrm{KBr}$ pellet, $\left.\mathrm{cm}^{-1}\right): 3046,3027,2923,2852,1628$, 1468 1385, 1301, 1183, 1099, 948, 810; ${ }^{1} \mathrm{H}$ NMR $\left(\mathrm{CDCl}_{3}, \delta, \mathrm{ppm}\right): 8.02-7.38$ (m, broad, Ar-H), 7.13-6.98 (m, broad, vinylic), $6.72(\mathrm{~s}, 2 \mathrm{H}), 6.48(\mathrm{~s}, 2 \mathrm{H}), 6.45(\mathrm{~s}, 2 \mathrm{H})$, $6.20(\mathrm{~s}, 2 \mathrm{H}), 4.92$ (s, broad, $-\mathrm{N}^{+} \mathrm{CH}_{2}$ ), 4.03 (s, broad, $\left.\mathrm{NCH}_{2}\right), 2.04\left(\mathrm{~m}\right.$, broad, $\alpha-\mathrm{CH}_{2}$ of octyl group at 9-position of fluorine), 1.80-1.09 (m, 76H, $\left.\mathrm{CH}_{2}\right), 0.87-0.79(\mathrm{~m}, 12 \mathrm{H})$.

${ }^{13} \mathrm{C} \mathrm{NMR}\left(\mathrm{CDCl}_{3}, \delta, \mathrm{ppm}\right): 179.32,170.25,154.46,143.62,141.32,139.88,138.76$, 
$128.44,125.78,124.05,116.03,55.41,46.75,46.26,34.23,31.95,31.84,30.16$, 29.88, 29.62, 29.54, 29.48, 29.42, 29.25, 28.87, 26.51, 22.72, 22.61, 21.20, 14.13, 13.09. Anal. Calcd for $\left(\mathrm{C}_{57} \mathrm{H}_{74} \mathrm{~N}_{2} \mathrm{O}_{2} \bullet \mathrm{H}_{2} \mathrm{O}\right)$ : C, 81.77; $\mathrm{H}, 9.15 ; \mathrm{N}, 3.35$. Found: $\mathrm{C}$, 81.84; H, 9.14; N, 3.38 .

P2: dark-blue powder, yield $68 \%$, IR $\left(\mathrm{KBr}\right.$ pellet, $\left.\mathrm{cm}^{-1}\right): 3046,3027,2922,2849,1623$, 1465, 1383, 1297, 1180, 1098, 947, 809; ${ }^{1} \mathrm{H}$ NMR ( $\left.\mathrm{CDCl}_{3}, \delta, \mathrm{ppm}\right):$ 7.35-7.98 (m, broad, Ar-H), 6.96-7.14 (m, broad, vinylic), $6.70(\mathrm{~s}, 2 \mathrm{H}), 6.45(\mathrm{~s}, 2 \mathrm{H}), 6.44(\mathrm{~s}, 2 \mathrm{H})$, $6.18(\mathrm{~s}, 2 \mathrm{H}), 4.89\left(\mathrm{~s}\right.$, broad, $\left.-\mathrm{N}^{+} \mathrm{CH}_{2}\right), 4.00$ (s, broad, $\left.\mathrm{NCH}_{2}\right), 2.01\left(\mathrm{~m}\right.$, broad, $\alpha-\mathrm{CH}_{2}$ of octyl group at 9-position of fluorine), $1.09-1.80\left(\mathrm{~m}, 76 \mathrm{H}, \mathrm{CH}_{2}\right), 0.80-0.88(\mathrm{~m}, 12 \mathrm{H})$. ${ }^{13} \mathrm{C} \mathrm{NMR}\left(\mathrm{CDCl}_{3}, \delta, \mathrm{ppm}\right): 176.80,169.22,151.54,141.59,140.06,139.87,138.90$, $128.26,125.54,123.98,115.15$, 55.32, 46.71, 46.24, 34.24, 31.96, 31.64, 30.06, 29.74, 29.71, 29.64, 29.59, 29.41, 29.28, 28.86, 26.52, 22.73, 22.63, 21.22, 14.16, 14.10. Anal. Calcd for $\left(\mathrm{C}_{77} \mathrm{H}_{114} \mathrm{~N}_{2} \mathrm{O}_{2} \cdot \mathrm{H}_{2} \mathrm{O}\right): \mathrm{C}, 82.74 ; \mathrm{H}, 10.46 ; \mathrm{N}, 2.51$. Found: $\mathrm{C}$, 82.78; H, 10.46; N, 2.54.

\section{Acknowledgements}

This work was supported by the key foundation of education ministry of China (No. 105142), the Doctoral Program Foundation of Institutions of Higher Education of China (No. 20030610069) and the Sichuan Province Science Foundation for Youths (No. 03SQ04).

\section{References}

[1] Muehlbacher, D.; Scharber, M.; Morana, M.; Zhu, Z.-G.; Waller, D.; Gaudiana, R.; Brabec, C. Advanced Materials. 2006, 18, 2884.

[2] Zhu, Z.-G.; Waller, D.; Gaudiana, R. et.al. Macromolecules 2007, 40, 1981.

[3] Tan, Z.-H.; Zhou, E.-J.; Yang, Y.; He, Y.-J.; Yang, C.-H.; Li, Y.-F. European Polymer Journal 2007, 43, 855.

[4] Lee, S.K.; Cho, N. S.; Kwak, J. H.; Lim, K. S.; Shim, H.-K.; Hwang, D.-H.; Brabec, C. J. Thin Solid Films 2006, 511, 157.

[5] Kim, S.C.; Naidu, B. V.; Lee, S.-K.; Shin, W.-S.; Jin, S.-H.; Jung, S.-J.; Cho, Y.-R.; Shim, J.-M.; Lee, J. K.; Lee, J. W.; Kim, J. H.; Gal, Y.-S. Solar Energy Materials \& Solar Cells 2007, 91, 460.

[6] Patricia S. F.; Ullich S.; Maximilien .;Emil J. W. e-Polymers 2002, no. 009.

[7] Zhu, Y.; Champion, R.D.; Jenekhe, S.A. Macromolecules 2006, 39, 8712.

[8] Wang, X.-H.; Hofmann, O.; Das, R.; Barrett, E.M.; de Mello, A.J.; de Mello, J.C.; Bradley, D. C. Lab on a Chip 2007, 7, 58.

[9] Sariciftci, N. S. Materials Today 2004, 7, 36.

[10] Nelson, J. Current Opinion in Solid State \& Materials Science 2002, 6, 87.

[11] Inaoka, S.; Roitman, D. B.; Advincula, R. C. Chemistry of Materials 2005, 17, 6781.

[12] Li, B.; Xu, X.-J.; Sun, M.-H.; Fu, Y.-G.; Yu, G.; Liu, Y.; Bo, Z. Macromolecules 2006, 39, 456 .

[13] Ralf, P.; Minquan, T.; Satoshi, T.; Makoto, F. Dyes and Pigments 2003, 57, 43.

[14] Wei, Z., Yuan, J.-H.; Xue, S.-W.; Zhang,B.-W.; Yi, C., Rong, Y. Solar Energy Materials \& Solar Cells 1999,58, 173.

[15] Ajayaghosh, A. Chem. Soc. Rev. 2003, 32, 181.

[16] Raymond B.; Majid M.; Jason S. Tetrahedron 2004, 60, 8913.

[17] Anuragudom, P.; Newaz, S. S.; Phanichphant, S.; Lee, T. R. Macromolecules 2006, 39, 3494. 
[18] Ajayaghosh, A.; Carol, P.; Sreejith, S. Journal of the American Chemical Society 2005, 127, 14962.

[19] Eldo, J.; Ajayaghosh, A. Chem. Mater. 2002, 14, 410.

[20] Hu, W.; Jiang, J.; Nakashima, H.; Luo, Y.; Kashimura, Y. et.al. Physical Review Letters 2006, 96, 27801.

[21] Trznadel, M.; Pron, A.; Zagorska, M. Synth. Met. 1999, 101, 118.

[22] Leeuw, D.M.; Simenon, M.M.J.; Brown, A. R.; Einerhand, R.E.F. Synth. Met. 1997, 87, 53. 